\title{
„ABY POJĄĆ PARYŻ, TRZEBA DLUGO ŻYĆ Z PARYŻEM"..." \\ FRANCUSKIE WRAŻENIA Z PODRÓŻY ŁUCJI Z KSIĄŻĄT GIEDROYCIÓW RAUTENSTRAUCHOWEJ
}

Ileż jest miast bez porównania piękniejszych od Paryża! Petersburg swymi marmurowymi pałacami, złoconymi kopułami, swym całym orientalnym przepychem, bardzo łatwo go przewyższy, Konstantynopol ma meczety, poetyczną oryginalność. Starożytny Rzym dumne wspomnienia. Nawet aż do świeżego i chędogiego Berlina, z piękną architekturą, szerokimi i prostymi ulicami, każda $\mathrm{z}$ tych stolic hardym okiem spojrzeć może na okopcony, błotnisty i smrodliwy Paryż.

Wszelako zapytaj wrzącego pragnieniem życia młodziana, odkąd chce swe podróże rozpocząć? powie od Paryża. Pytaj go: po zwiedzeniu Europy dokąd chciałby powrócić? zawoła: do Paryża! Każdy dumniej powtarza swe paryskie wspomnienia, ciekawiej go słuchają, niż gdyby z Chin wracał, a jednak któż o Paryżu nie słyszał? któż mniej więcej go nie zna z licznych opisów? Gdzież Paryża nie naśladują?

Obyczaje jego chwytane, przywłaszczane jak najspieszniej, monopol gustu i mody, zdaje się na zawsze mu oddany. Wielu i bardzo wielu, jak w nim pomieszkają, już gdzie indziej żyć i umierać nie chcą.

Mimo to, każdy przybywający do Paryża, z niemiłym zdumieniem dziwi się jego sławie, i w pierwszych dniach wiele niesmaku znajduje. Paryż jest jak brzydka kobieta, wielkich cnót i zalet, gruntownej dobroci. Wszedłszy

1 Łucja z książąt Giedroyciów Rautenstrauchowa, Wspomnienia moje o Francyi, Kraków 1839, s. 146. 
do świetnego zgromadzenia nikt na nią spojrzeć nie chce, bo jedne wabią oko wyborowym strojem, drugie przepychem, inne wdziękami, ona niczym. Każdy się zrazu dziwi mnogim namiętnościom, jakie wzbudzała i wzbudza, lecz wkrótce o pięknych i strojnych zapomina dla niej, wyrzeka się ich, całą swą cześć jej pod nogi ścieląc².

Ten obszerny cytat w doskonały sposób obrazuje charakter stolicy Francji. Od czasów późnego średniowiecza bowiem Paryż był nieustannie celem podróży wszystkich Europejczyków. Uważany za centrum kultury, mody i polityki ówczesnego świata przyciągał ludzi wszystkich stanów, a szczególnie arystokracji. W piśmiennictwie nowożytnym tradycję podróżopisarstwa zapoczątkowały XVIIIi XIX-wieczne relacje $\mathrm{z}$ autentycznych wypraw, w szczególności z modnej ówcześnie i stanowiącej główny model i kanon podróżowania - tzw. grand tour, wielkiej podróży, dopełniającej edukacji i awansującej do elity towarzyskiej.

Niezależnie od tego, jaką trasę opracowano, obowiązkowo musiał znaleźć się w niej Paryż. Podróż do stolicy Francji traktowano nie tylko jako okazję do poznania kultury, czy mody, lecz także jako miejsce, gdzie można było zawrzeć ważne znajomości z politykami, ale również z francuską arystokracją, które zaowocują w przyszłości. Do najsławniejszych podróżników do Paryża należeli m.in. wojewodzic lubelski Jakub Sobieski, późniejszy kasztelan krakowski, który swoje wrażenia z zagranicznej wyprawy spisał w formie pamiętników ${ }^{3}$ oraz jego syn Jan - późniejszy król Jan III Sobieski - znany frankofil w życiu politycznym.

Fascynacja Francją wśród polskich elit rozpoczęła się na dobre w XVIII wieku. O ile dla szlachty początkowo Francja jawiła się jako ostoja despotyzmu i absolutyzmu królewskiego, o tyle w dobie powolnego upadku Rzeczpospolitej oglądano się na nią jako na przyszłą sojuszniczkę i wyzwolicielkę ze strefy wpływów Rosji, Austrii i Prus. Pierwszymi oznakami zwrotu ku Francji była elekcja francuskiego

\footnotetext{
Tamże, s. 144-146.

Jakub Sobieski, Peregrynacja po Europie (1607-1613). Droga do Baden (1638), oprac. Józef Długosz, Wrocław 1991.
} 
kandydata Franciszka Burbona, księcia Conti, na króla w 1697 roku Kolejnym elementem wzmocnienia stosunków polsko-francuskich był ślub córki wojewody poznańskiego Stanisława Leszczyńskiego - wieloletniego i pechowego kandydata na tron polski - Marii z młodym francuskim monarchą Ludwikiem XV. Zaowocowało to zwiększeniem zainteresowania Wersalu sytuacją w Polsce.

Przyjaźń polsko-francuska rozkwitła w czasach Wielkiej Rewolucji oraz epoki napoleońskiej, oficjalnie walczącej z „despotyzmami” królewskimi, które idealnie uosabiali monarchowie austriacki, rosyjski i pruski. Zwłaszcza w dobie Sejmu Wielkiego widać było, jak bardzo francuskie prądy rewolucyjne wpływały na działalność polskich polityków. Polskie elity spodziewały się dużej pomocy ze strony „ojczyzny postępu", jednak ta ostatnia wspierała Polaków bardziej z powodu szansy na związanie wojsk trzech mocarstw nad Wisłą.

Czasy Napoleona Bonaparte jeszcze bardziej wzmocniły tę w gruncie rzeczy nieodwzajemnioną miłość. Cesarz Francuzów wprowadził sprawę polską do międzynarodowej dyskusji, dlatego wiązano z nim nadzieje odbudowy niepodległej Rzeczpospolitej. Wielu Polaków robiło dzięki Francuzom duże kariery, nie tylko we własnym kraju, lecz także nad Sekwaną. Stąd silne związki polskich elit z Francją. Jednym z polskich arystokratów, mających dość mocną pozycję w oczach Napoleona, był książę Romuald Giedroyć, ojciec Łucji Rautenstrauchowej. Choć w swoich wspomnieniach autorka mocno przeszacowała jego wpływy, nie zmieniało to faktu, że istniały silne polsko-francuskie związki. Dlatego nie można się dziwić, że po upadku powstania listopadowego arystokracja powstańcza szukała schronienia właśnie we Francji. Innym powodem takiej sytuacji mogły być również silne wpływy kultury francuskiej w Europie, sięgające czasów Ludwika XIV, kiedy to dwór Króla Słońce wskazywał trendy tak w modzie, jak w kulturze i sztuce. Znajomość języka francuskiego była wtedy powszechna zarówno wśród elit, jak i artystów. Literaturę francuską

\footnotetext{
4 Sam książę nie wykazywał większej ochoty do objęcia władzy, co wykorzystał jego główny konkurent, elektor saski - książę Fryderyk August Wettyn.
} 
czytano tylko w oryginale. Krzepiono się także promieniejącą z Francji na Europę ideologią liberalizmu, łudzono co do niezwykłego zainteresowania Francji losem Polski. Wreszcie gdy w czasie powstania listopadowego spodziewano się rychłej pomocy z Zachodu, na Francję liczono przede wszystkim. Naturalną konsekwencją tych zjawisk było uznanie Paryża za idealne miejsce do dyskusji na temat powstania ${ }^{5}$.

Jak to zwykle bywa w polskiej historii, zaraz po zakończeniu walk rozpoczęły się licytacje pod hasłem: kto winien upadku? Jeszcze zimą 1831 roku w Dreźnie, gdzie zbierali się byli powstańcy, rozpoczęły się kłótnie nie tylko o działania wojenne, lecz także o koncepcje polityczne. Ponieważ król saski nie mógł długo tolerować obecności tylu Polaków w Dreźnie ze względu na naciski Prus, politycy niebawem wyjechali na zachód, kierując się do Francji. Tak zrodził się ruch znany szerzej pod nazwą Wielkiej Emigracji. Wbrew pozorom nie objęła ona znacznej części społeczeństwa (oblicza się, że było to ok. 10 tys. osób), chodzi tu raczej o jakość tej emigracji, w znacznej mierze były to elity polityczne i kulturalne dawnej Kongresówki ${ }^{6}$.

W ślad za nimi ruszyła również Łucja z książąt Giedroyciów Rautenstrauchowa, urodzona w 1798 roku w Bobcinie na Litwie polska pisarka, córka generała lejtnanta Romualda Giedroycia, żona generała Józefa Rautenstraucha ${ }^{7}$, urzędnika oddanego władzy carskiej. Około 1831 roku jej małżeństwo z dużo starszym generałem już od dawna nie układało się najlepiej. Dla osoby z jej pozycją wyjazd za granicę wydawał się być naturalnym rozwiązaniem krępującego ją związku. Rozwód nie wchodził w grę, o wiele lepszym posunięciem wydawał się wyjazd do Paryża, do matki i siostry ${ }^{8}$.

\footnotetext{
5 Alina Kowalczykowa, Francusko-polskie zwiazki literackie, hasło w: Słownik literatury polskiej XIX wieku, pod red. Józefa Bachórza i A. Kowalczykowej, Wrocław 2009, s. 306.

${ }^{6}$ Potoczne określenie powstałego w wyniku postanowień Kongresu Wiedeńskiego (1814-1815) Królestwa Polskiego.

Józef Rautenstrauch (1773-1842), polski i rosyjski generał dywizji, od 1832 Prezes Teatrów Rządowych w Królestwie. Zbigniew Zacharewicz, Józef Rautenstrauch, w: Polski Stownik Biograficzny, t. 30, Wrocław 1987, s. 657.

Karolina Anna Borzymowska (1766-1858) oraz Kunegunda z książąt Giedroyciów Białopiotrowiczowa (1793-1883), literatka i działaczka społeczna.
} 
Po kilkuletnim pobycie w stolicy Francji generałowa wydała Wspomnienia moje o Francyi - zbiór wrażeń, obserwacji i refleksji wyjątkowy głównie ze względu na swoje niezwykłe walory poznawcze. W spisanych po zakończeniu pobytu nad Sekwaną wspomnieniach Rautenstrauchowa starała się ukazać prawdziwy obraz miasta.

Choć do lat 30. XIX wieku rozwija się i dominuje wśród relacji podróżniczych „podróż sentymentalna” (np. Konstancji Biernackiej, Podróż z Włodawy do Gdańska powrotem do Nieborowa w roku 1816, wyd. w 1823 r., czy Klementyny Hoffmanowej, Opisy różnych okolic Królestwa Polskiego, wyd. w 1833 r.) i nadal silnie obecna jest relacja $\mathrm{z}$ trasy grand tour, to jednak Wspomnienia moje o Francyi w niczym nie przypominają tych typów literackich ${ }^{9}$. W swym dziele Rautenstrauchowa daleka jest również od uprawiania romantycznego stylu podróżopisarstwa, w którym dominowałyby wzniosłe treści społeczne, moralne, psychiczne, egzystencjalne. Wspomnieniom... najbliżej jest do obyczajowo-towarzyskiej podróży do wielkiej stolicy, związanej z ówczesną kulturą, a także do jeszcze dwóch innych nurtów - wykorzystania toposu literackiego podróży oraz poezji topograficznej (opisowo-wspomnieniowej), opartej na motywie wspomnienia z podróży. Osoba narratorki oraz zwiedzane miejsca są tu jak najbardziej autentyczne, natomiast obraz świata podlega przekształceniom właściwym dziełu literackiemu w zakresie operowania czasem, przestrzenią oraz sposobem prowadzenia akcji.

We Wspomnieniach moich o Francyi autorka skupia się przede wszystkim na opisaniu świata zewnętrznego: obyczajów, mód, francuskiej ulicy, salonu czy historii odwiedzanych miejsc. Niewiele miejsca poświęca bardziej doniosłym treściom egzystencjalnym.

Oddajmy głos samej Rautenstrauchowej, nikt bowiem lepiej od niej nie oprowadzi nas po tym dziewiętnastowiecznym mieście, nie pokaże

\footnotetext{
9 Janina Kamionka-Straszakowa, Podróż, hasło w: Stownik literatury polskiej XIX wieku, dz. cyt., s. 700 .
} 
jego piękna, ale i słabości. W przemyśleniach spisanych cztery miesiące po wyjeździe z Paryża ${ }^{10}$, generałowa tak wspomina swoją podróż:

Przyjechałam tą razą do Paryża dnia 24 października 1832 roku. Część Francji, od Forbach i Metz, nie odpowiedziała mojemu oczekiwaniu. Jadąc przez południowe Prusy, przez wszystkie nadreńskie kraje, gdzie nędza $\mathrm{z}$ imienia nawet zdaje się nieznana, uważając ten postęp razem z cieplejszym rozwijający się niebem, pyta każdy: cóż będzie we Francji, kiedy tu już taki porządek rzeczy panuje? Tymczasem wjechawszy do owego mniemanego Eldorado, spostrzegamy zabudowania chłopskie uboższe, wszędzie mniej ochędóstwa, mniej dostatku widać, a położenia, widoki, nie zasługują prawie na uwagę. Tak smutnie zawiedziona mniemałam, że widok Paryża wszystko mi wynagrodzić zdoła. Wzdychałam do chwili przyjazdu; a trzeciego dnia po przebyciu granicy, ciągle wysuwałam głowę w nadziei, iż spostrzegę stolicę świata. Jakoż ku wieczorowi spostrzegam z daleka kłęby dymów wznoszące się nad niezliczoną ilością dachów, kominów, wież, wieżyczek, kopuł itd.; roztwieram jeszcze lepiej oczy, natężam uwagę, ale już nic nie widzę, bośmy wjechali w jakąś wąską i brudną uliczkę. Ta czasem się rozszerza, czasem się nawet przerwie na chwilę, lecz rozpoczyna się na nowo, ze ścieśnionymi z obu stron domami i zupełnie wszelki widok ogólny tamuje. W uliczce mnóstwo sklepów, ruch wielki, krzyżują się pojazdy, brzydkie wprawdzie, ale dziwacznej postaci. Nie przypuszczam żeby to był Paryż; nie widząc jednak końca tej ulicy czy miasta, pytam się postyliona jak się zowie to miejsce. Powiada mi, że tu nie jedna niegdyś, ale kilka wsi było, i każda z nich dotąd jeszcze osobne zachowała nazwisko. Miały dawniej własne także granice, bo dziś zupełnie prawie połączyły się z sobą i jedną niejako wieś tworzą, która paryskiego przedmieścia dotyka. Zaspokojona tą odpowiedzią, postanowiłam cierpliwie czekać bram paryskich, nie nudząc już biednego postyliona mymi pytaniami, które mu się mogły śmiesznymi wydawać. Jakoś siadłam spokojnie i patrzałam; ale już nic nie widziałam nowego. Ruch był wprawdzie coraz większy, coraz więcej dziwnych pojazdów, a z uliczki w uliczkę wjeżdżając, coraz prawie brudniejszą i ciaśniejszą, zdawało się iż w jakimś ulicznym labiryncie błądzimy, który jeżeli ma początek, nie zdawał się mieć końca. Nigdzie żadnej rogatki, żadnej bramy nie spostrzegłam, nigdzie nie zatrzymywano pojazdu, nigdzie o nic nie pytano...

10 Łucja z książąt Giedroyciów Rautenstrauchowa, dz. cyt., s. 3. 
Znudzona, może nawet niespokojna dokąd mię tak wiozą, zerwałam postanowienie, a kazawszy stanąć (bo dla hałasu nie można było inaczej z postylionem rozmawiać), zaczęłam pytać, jak daleko i kiedy dojedziemy do tego sławnego i tak długo oczekiwanego Paryża? - A już od godziny w nim jesteśmy - Jak to w Paryżu? I to co widzę, jestże to Paryż? - Tak, niezawodnie jesteśmy w Paryżu. Już się zmierzchać mocno poczynało. W ciasnych uliczkach paryskich, gdzie z obu stron, sześciu lub siedmiopiętrowe domy światło tamują, noc o godzinę pierwej niż w reszcie świata zapada. Dowiedziawszy się że jestem w Paryżu, podwajałam uwagę, lecz tak źle oświecone miasto rzadko gdzie widzieć można. Mając w świeżej pamięci czysty i elegancki Berlin, cały co wieczór gazem jaśniejący, a z każdej strony swych prostych i szerokich ulic, jakby girlandę z gęsto wiszących latarni przedstawiający oku, żadnym sposobem pojąć nie mogłam, dla czego Paryżanie na taką ciemnotę skazani. Dziwiłam się, iż tyle przywiązując ceny do wygód życia, nawet do wymysłów, tak cierpliwie znoszą jedną z największych nieprzyjemności, zwłaszcza w mieście, gdzie bardzo często, a w niektórych ulicach nieustannie bywa błoto. Wkrótce już nic dojrzeć nie mogłam, czułam tylko zaduch niemiłych wyziewów. Kiedy niekiedy, przesunęła się koło mnie jakaś poczwórna kareta, z dwiema latarenkami na przodzie. Pod ich światłem dojrzałam, iż te powozy zaprzężone dwiema wychudłymi szkapami, mają numera na drzwiczkach lub pod kozłem, stąd się domyśliłam że to są fiakry, lecz zdumiewałam się nad ich niepochlebną powierzchownością. Bardziej jeszcze zadziwiły mię, zbliżające się dwa światełka kolorowe, czerwone, żółte lub zielone, albo jedno zielone drugie czerwone. Były to omnibusy; dla odróżnienia, i aby je z daleka rozpoznać można, kolorowymi latarniami oświecone. Jeszcze z pół godziny po ciemnych błądząc zakątkach, uczułam na koniec wolniejsze nieco powietrze. Ucieszyłam się nadzieją, iż w przestronniejszym znajdę się miejscu [...] Wiedziałam, żem na jednej z pierwszych ulic sąsiednich bulwarów wysiadła; a gospodyni zalecając mi dom swój, opowiedziała, że należy do eleganckiej części Paryża, że najpierwsze modniarki, sama nawet Baudran ${ }^{11}$ na niej mieszka, i że się zowie ulicą Nową Sgo Augustyna (rue neuve St. Augustin). Po takowej rekomendacji, ciekawa poznać tę elegancka ulicę, wysuwam głowę, lecz oko moje zdziwione nie daleko sięgnąć może. Domy wprawdzie wysokie, ale nie wspaniałe, nie ozdobne,

11 Kazimierz Kaszewski, Łucja z książąt Giedroyciów Rautenstrauchowa (wspomnienie pośmiertne), „Kłosy” 1886, nr 1090, s. 310. 
czystością się nawet nie odznaczają. Sklepy jeszcze pozamykane; wszystko we śnie pogrążone. Biedniejące rewerbery rzucają resztę konającego światła, na stosy śmieci i błota przed każdym domem skupione, a środkiem ciągną wozy na rynek ${ }^{12}$.

Tą na wpół humorystyczną historią Rautenstrauchowa rozpoczyna opowieść o swoim pobycie w Paryżu, dzięki relacji Kazimierza Kaszewskiego wiemy jednak, że jej pojawienie się w stolicy Francji nie było z początku dobrze postrzegane: „Jak to opowiadała w poufnej rozmowie, emigracja przypisywała jej przybyciu jakiś powód natury politycznej, rozumie się z uwagi na stanowisko jakie podówczas zajmował jej mąż, i prawie pewną będąc ukrytego planu, rozpoczęła z nią rodzaj traktowania, którego zrazu generałowa nie zrozumiała, aż wreszcie udało się jej wyprowadzić traktujących z błędu"13. Rautenstrauchowej istotnie z dużą wprawą udało się wyjaśnić to nieporozumienie, gdyż w Paryżu spędziła kolejne sześć lat, doskonale odnajdując się w środowisku polskiej emigracji. Z racji pochodzenia i prezentowanych poglądów dla generałowej naturalnie bliskim towarzystwem było otoczenie Hotelu Lambert. Skupiał on główny nurt polskiego konserwatyzmu. U zarania swojej działalności gromadził przede wszystkim elity polityczne Kongresówki oraz pochodzących z Litwy uczestników powstania listopadowego. W większości była to bogata arystokracja lub wyżsi zawodowi wojskowi. Konserwatyzm księcia Adama miał wpływ na eksplozję kulturową doby Wielkiej Emigracji. Czartoryski wspierał finansowo lub poprzez swoje koneksje takie osobistości jak: Adam Mickiewicz, Juliusz Słowacki czy Fryderyk Chopin. Oni z kolei odwdzięczali się swego rodzaju wiernością. Słowacki jeszcze w czasie powstania listopadowego jako młody urzędnik Rady Stanu został wysłany z misją dyplomatyczną do Londynu. Z kolei podróżujący po całej Europie do walczącej Warszawy Mickiewicz w późniejszych latach reprezentował Hotel Lambert w różnego rodzaju kon-

\footnotetext{
12 Łucja z książąt Giedroyciów Rautenstrauchowa, dz. cyt., s. 47-64.

13 Kazimierz Kaszewski, dz. cyt., s. 310.
} 
fliktach europejskich jako tytularny przywódca Legionu Polskiego w Rzymie w 1848 roku czy jako przedstawiciel Hotelu Lambert, współorganizując dywizję jazdy w wojnie krymskiej. Za to ostatnie poświęcenie zapłacił życiem - zmarł na cholerę w 1855 roku w Konstantynopolu.

Można powiedzieć, że w 1832 roku Rautenstrauchowa znalazła się w odpowiednim miejscu w odpowiednim czasie. Polacy byli w Paryżu popularni do tego stopnia, że w sezonie karnawałowym 1832/1833 modne były nie tylko czapki krakuski i kontusze, ale wszystko, co miało jakikolwiek związek z Polską. Liberalna Europa patrzyła na powstańców jak na bohaterów walki z despotyzmem, na podróżujących na zachód czekały różnego rodzaju bramy triumfalne, huczne powitania, a nawet wsparcie finansowe. W tak sprzyjających okolicznościach młoda generałowa nawiązywała kontakty z wieloma wybitnymi postaciami Wielkiej Emigracji. Jeszcze w 1832 roku poznała Adama Mickiewicza ${ }^{14}$.

Rautenstrauchowa, jak wiemy, wiele czasu poświęcała na zwiedzanie Paryża. Niektóre ze swych wycieczek odbywała wieczorem po wspaniałych, budzących zachwyt paryskich ulicach:

[...] ujrzałam szeroką ulicę, z obu stron dwoma rzędami drzew wysadzoną. Domyśliłam się, że są to owe zawołane Bulwary. Dziwiła mię ich ponurość, kiedy w parę minut, jakby czarodziejską władzą przeniesiona, znalazłam się w miejscu najświetniejszym tysiącami ogniów jaśniejącym. Światła te padały z licznych sklepów, bogato gazem oświeconych, i z salonów tak błyskliwych jak gdyby do balu przygotowane były. Większe jeszcze na mnie ten cały blask sprawił wrażenie, gdym wychodziła z ciemności. Ten thum hucznych, wesołych ludzi snujący się pomiędzy drzewami, w pośród ozdobnych, przepysznych magazynów, cudny zaiste przedstawia widok. Tu na iluminowanych gradusach wystawiono kilkaset prześlicznie wyrobionych zegarów, marmurowych, brązowych, alabastrowych, tam na podobnych schodach kryształy i porcelany stoją, tu znowu pióra i kwiaty wyrabiane, tam posągi i inne kunsztowne wyroby. Za nimi przez szklane

14 Maria Dernałowicz, Kronika życia i twórczości Mickiewicza. Marzec 1832 - czerwiec 1834, Warszawa 1966, s. 142. 
ściany widać cukry naśladujące brylanty, lalki, altany lub zwierzęta. W drugim sklepie już nie cukrowe brylanty, lecz prawdziwe szmaragdy, diamenty, rubiny, i co tylko zbytek z gustem połączony przemyślić może. Obok niego skład sukien męskich, dalej stroje i kapelusze damskie, tu srebra, tam owoce i kwiaty świeże, wszystko z największym kunsztem, z wyrachowaną ułożone kokieterią, odbija się w tylnych ścianach zwierciadłami pokrytych, tak że oko złudzone nie wie ku czemu się zwrócić, gdzie się zastanowić, czym się bardziej zachwycić! Sale zaś, które mi się zdawały do balu gotowe, są to zwyczajne kawiarnie. Całe zwierciadłami, lustrami, draperiami strojne, od ulicy szkłem przejrzystym oddzielone, zdumiewają i nęcą przechodnia. W koło marmurowych, brązem opasanych stolików, licznych widać płci obojej gości, pośród nich, schludni, zwinni posługacze roznoszą chłodniki, ciepłe napoje lub potrawy ${ }^{15}$.

Jednak Paryż o poranku nie zawsze prezentuje się równie okazale: „[...] ciekawa poznać tę elegancką ulicę [rue neuve St. Augustin M.A.], wysuwam głowę, lecz oko moje zdziwione nie daleko sięgnąć może. Domy wprawdzie wysokie, ale nie wspaniałe, nie ozdobne, czystością się nawet nie odznaczają. Sklepy jeszcze pozamykane, wszystko we śnie pogrążone. Bledniejące rewerbery rzucają resztę konającego światła na stosy śmieci i błota przed każdym domem skupione, a środkiem ciągną wozy na rynek"16. Również po wyjściu na ulicę Rautenstrauchowa nawet na chwilę nie traciła niczego ze swej czujności obserwatorki:

Błoto było niesłychane [...]. Ulice już były przepełnione ludźmi. W postaci każdego widać było zajęcie i pośpiech, a pomimo błota nie dostrzegłam nikogo idącego powoli. Każdy był obryzgany i zaszargany po kolana, a kapelusz i plecy zasłaniał dużym czarnym deszczochronem. [...] Potrącana i ślizgając się w tej pierwszej po Paryżu wędrówce, która mi się bez końca długą wydawała, tę przynajmniej znajdowałam przyjemność, iż kogokolwiek zapytałam o drogę, czy to komissyonera z tragami, stojącego na rogu ulicy, czy którego ze spieszących ichmościów, każdy jak najuprzejmiej i z dokładnością świadczącą o zwyczaju i biegłości podobnych

15 Łucja z książąt Giedroyciów Rautenstrauchowa, dz. cyt., s. 52-53.

16 Tamże, s. 56-57. 
informacji, wskazywał mi dokąd mam, w prawo, czy w lewo się udać. A jakaś kupcowa u drzwi sklepu stojąca, postrzegłszy u mnie odwiązany trzewik, ostrzegła mię zapraszając abym do niej weszła. Tam zmusiła mię do postawienia obłoconej nogi na czystym i porządnie obitym krześle, a swą chustką wytarłszy powalaną wstążeczkę, zawiązała ją, oglądając i drugie obuwie, abym powtórnie podobnej nie uległa przygodzie. Jest to grzeczność, że tak nazwę, uliczna, Paryżowi właściwa. Daje ona może zbyt wysokie wyobrażenie o cywilizacji Francji, łudzące o towarzystwie wznieca nadzieje $[\ldots]^{17}$.

Bardzo często można odnieść wrażenie, że Rautenstrauchowa w swoich obserwacjach bywa ironiczna i złośliwa, czasem wręcz zbyt surowa dla tego wspaniałego miasta. Nie należy jednak zapominać, że pisarka doskonale poznała materię, z którą przyszło jej się zmierzyć. Przebywając jako dziecko w Paryżu ${ }^{18}$ miała okazję od najmłodszych lat obserwować świat francuskiej stolicy. To zatem, co wielu mogłoby poczytać za słabość tych wspomnień, czyni je jeszcze cenniejszymi i stawia ponad innymi.

Rautenstrauchowa przystępowała do spisania swych wrażeń bez bagażu kompleksów obywatelki dalekiego kraju, w jej relacji nie znajdziemy sztucznych zachwytów ani niepotrzebnej uniżoności w kontaktach z ludźmi więcej od niej znaczącymi. Wręcz przeciwnie - ze Wspomnień... wyłania się obraz wykształconej arystokratki, trzeźwo patrzącej na otaczającą ją rzeczywistość, która nie czuje się w obowiązku hołdować światu, którego zasad nie pochwala.

W swych wędrówkach po Paryżu generałowa nie zawsze jest sama, towarzyszy jej często przyjaciel, którego sama nazywa „Cicerone”. Przewodnik ów zwiedza z nią miasto, pokazując najpiękniejsze miejsca:

Z jednej strony Sekwana, na niej most wspaniały, posągami sławnych ludzi ozdobny. Prowadzi on do izby poselskiej, a ten gmach swym pysznym

17 Tamże, s. 67-69.

18 Siostra Rautenstrauchowej, Kunegunda Białopiotrowiczowa była damą dworu cesarzowej Józefiny. 
frontem, z szerokimi zewnętrznymi schodami, poprzedzonymi od czterech alegorycznych posągów, ogranicza dalszy widok. Z przeciwnej strony dwie okazałe budowle, pomiędzy nimi bierze początek szeroka i prosta ulica królewska (rue Royale), symetrycznie z obu stron zabudowana domami, zakończona placem, w pośród którego wznosi się kościół Ś. Magdaleny, jeden z najpiękniejszych utworów architektury rzymskiej. W prawo ginie oko w długiej cienistej ulicy Pól Elizejskich (Champs Elisées), ludem i ruchem całego Paryża ożywionej, zakończonej olbrzymią bramą tryumfalną, wieńczącą wszystkie wojskowe sławy wieku naszego, po lewej ręce widać kratę żelazną ogrodu Tuileryjskiego ze złoconymi ostrzami, z dwoma posągami przy wejściu, a wzdłuż ogrodu spostrzega się część najwspanialszej ulicy Rivioli, z jej krytymi chodnikami, arkadami, w których cieniu składy tego wszystkiego, co przemysł ludzki i kunszta wykształcić zdołały. Jest to podług mnie najciekawszy, najpiękniejszy punkt miasta, a dobrze zrozumiana kokieteria przewodnika, powinnaby raczej na nim kończyć, a nie zaczynać od niego ${ }^{19}$.

To jeden z nielicznych fragmentów Wspomnień..., w którym autorka z takim zachwytem opisuje miasto. Nie jest to rzecz jasna spowodowane jej sceptycyzmem wobec Paryża ani tym bardziej tego, co nieznane. Rautenstrauchowa nie tylko poprzez swoją twórczość, lecz także poprzez życie, jakie prowadziła, dała się poznać jako wykształcona i niezależna kobieta. Za każdym razem, gdy opisuje kolejne zwiedzane miejsca ${ }^{20}$, stara się patrzeć na nie obiektywnie. Często w swym opisie odwołuje się do Litwy, stawiając ją nieraz nawet ponad Włochami. Nie wynika to bynajmniej z jej tęsknoty za krajem lat dziecinnych, ani tym bardziej z braku obycia. Wręcz przeciwnie - autorka opiera się na własnych przekonaniach, na własnym, by tak rzec, systemie wartości, który został ukształtowany nie tylko w Bobcinie, lecz także w Warszawie, gdzie Rautenstrauchowa spędziła młodość, a dzięki ojcu, który dbał o wykształcenie i szerokie horyzonty córek, młoda Łucja miała

\footnotetext{
19 Łucja z książąt Giedroyciów Rautenstrauchowa, dz. cyt., s. 74-75.

20 Rautenstrauchowa w swoich kolejnych relacjach z podróży opisuje m.in. Berlin, Wenecję, Karlsbad, Marienbad, Wielkopolskę, Tatry.
} 
okazję już jako nastolatka i jedna z pierwszych kobiet w ogóle bywać na wykładach w Szkole Głównej.

Wróćmy jednak do Paryża i Ogrodu Tuileryjskiego. Niestrudzona obserwatorka zwracała tam uwagę nie tylko na modę paryżanek, o których napisała: „U nich to wprawdzie najwięcej spostrzegać się daje pretensji, chęci nagromadzenia ozdób, najczęściej przeciwnych dobremu smakowi, sprzecznych z dobrze rozumianą, prawdziwą elegancją"21, lecz przede wszystkim jej wzrok przyciągały dzieci:

Nic piękniejszego jak grono dzieci w Paryżu, dzieci od lat dwóch do siedmiu, kiedy jeszcze matkom w miejscu lalek za zabawkę a razem za ozdobę służą. [...] dzieci ich [paryżanek - M.A.] zawsze jakby z pudełka wyjęte, uczą się zawczasu gracji i zręczności, w licznych zabawach i grach na ten cel wymyślonych. [...] La petite Provence (tak bowiem zowią, nie wiem dlaczego, miejsce dla dzieci w Tuileryach wyznaczone, może $\mathrm{z}$ tego powodu iż z drzew obnażone, na całą działalność słońca jest wystawione jak Prowansja), mała więc Prowansja, zawsze prawie jest otoczona widzami, wielbicielami tego ładnego pokolenia. Gry i zabawy, jakby sztuki na scenie wystawiane, mają niezaprzeczoną wadę, iż zbyt wcześnie dzieci a szczególniej dziewczynki do zalotności zaprawiają. Matki, kilka razy pokazawszy się w modnej alei, wracają do dziecinnego placu z przyjaciółmi, ze znajomymi, a chcąc się pochwalić zgrabnością córeczek swoich, same je podniecają, wmawiają chęć i potrzebę podawania się za przedmiot admiracji. Wtenczas to podwieczorki także, kostiumowe baliki, komedie, tańce teatralne, więcej może dla zabawy matek aniżeli dzieci przemyślane, jeszcze bardziej rozwijają i na całe życie zaszczepiają tę próżnośćc2 ${ }^{2}$.

Dzieci były generałowej w naturalny sposób bliskie. Można to wywnioskować nie tyle z cytowanego fragmentu, ile śledząc koleje jej życia. Choć nieudane małżeństwo z Rautenstrauchem przekreśliło na zawsze szansę pisarki na zostanie matką, to jednak nie zrezygnowała z prób kontaktu z najmłodszymi. Już po wyjeździe z Paryża w 1838 roku prosiła Mickiewicza w listach by, jeśli urodzi mu się córka, oddał

\footnotetext{
21 Tamże, s. 89.

22 Tamże, s. 93.
} 
ją na wychowanie generałowej. Ostatecznie do niczego takiego nie doszło, Celina Mickiewiczowa w czerwcu 1838 roku urodziła syna, Władysława. Pokazuje to jednak determinację pisarki. Jej pragnienie spełniło się dopiero w 1844 roku - kiedy to po śmierci brata, Konstantego $^{23}$, przypadła jej w udziale opieka na dwuletnim wówczas bratankiem - Romualdem Giedroyciem ${ }^{24}$. Rautenstrauchowa często potrafi być ostrym krytykiem mentalności mieszkańców francuskiej stolicy, wytykając im przy tym zachłanność oraz brak zasad:

Interes, chęć nabycia, o ile możności jak największych bogactw, jako jedyny sposób osiągnięcia wszelkich życzeń, jest wyłącznym bodźcem działającym na zużywane czy omdlone serca teraźniejszych Francuzów. [...] Od pałaców począwszy i na nich najprzód wzrok zastanowiwszy, spuszczając go później stopniowo aż do najuboższego mieszkańca gałganiarza, wśród ciemnej nocy z latarką w ręku, dla lichego i niepewnego zarobku, grzebiącego w kupach błota i śmieci - wszędzie chęć zysku jest główną i jedyną sprężyną. Źle też powiedziałam, że Francja pozbawiona wiary. Wierzy Francuz, wierzy w nieomylność franka do pewnej matematycznej wyniesionego potęgi ${ }^{25}$.

Idąc jeszcze dalej w swych obserwacjach, tak Rautenstrauchowa pisze o giełdzie:

Na czworokątnym, przestronnym i okazałym placu wznosi się jeden z najpiękniejszych tego czesnych gmachów paryskich ${ }^{26}$. Ze wszech stron kolumnami ozdobiony. [...] Tam dopiero wszystkie industrialne pojęcia rozwijają się namiętnie! Tam w jednej godzinie dwoją się lub obalają majątki! [...] Na tych czerniących się wschodach, przed otwarciem podwoi, na żadnej twarzy nie dostrzeżesz tej nudy, tego zniechęcenia, o których wspominałam. Owszem, każdy rzeźwy, sprężysty, zajęty, każdy pełen życia, pełen zapału. A jeżeli przy wyjściu da się widzieć bladą martwością powleczone

23 Aleksander Konstanty Giedroyć (1805-1844).

24 Romuald Giedroyć (1842-1899), syn Aleksandra, żonaty z Barbarą von Brewern, http:// mariusz.eu.pn/genealogia/rody, dostęp: 19 maja 2013 r.

25 Łucja z książąt Giedroyciów Rautenstrauchowa, dz. cyt., s. 38-41.

26 Giełda papierów wartościowych mieszcząca się w Palais de la Bourse. 
czoło, takaż summa radości na innych za to przybyła. Nawet płeć piękna tak oblegała tę świątynię niestałej bogini, tak energicznie hołdować jej poczęła, iż dla zachowania reszty już i tak ginącego uroku tej połowy rodu ludzkiego, urzędownie wejście kobietom zabronione zostało...27.

Zwiedzanie miasta to oczywiście jedna z wielu rozrywek dam przebywających w stolicy. Do ważnych obowiązków należało także bywanie w towarzystwie. I tu również możemy liczyć na wnikliwą obserwację Rautenstrauchowej, która skrupulatnie odnotowuje mody panujące na salonach:

Są mody w Paryżu, do których każdy stosować się pragnie, których niktby przestąpić nie śmiał. Nikt by się na przykład nie poważył zganić dramę pana Hugo, a jeszcze bardziej wyznać, że ostatniej nie widział. Dość nie unosić się nad szczytnością poezji jego, aby otrzymać patent głupca w salonach paryskich. [...] Operę włoską trzeba koniecznie nad wszystkie teatry przekładać i unosić się nad muzyką włoską, tak obcą uszom francuskim. [...] Najgłówniejsza i można powiedzieć najpoważniejsza ze wszystkich mód przywiązana jest do zdań politycznych. Kto żadnej opinii nie głosi, nie broni, kto do żadnego nie wpisze się szeregu, osądzony jest za głupca. [...] Gdym przyjechała do Paryża, Polska jeszcze była w modzie, wszystkie nowości w każdym rodzaju, nawet potrawy, polski chrzest odebrać musiały. Przed wyjazdem moim Niemcy największą wziętość miały, muzyka, literatura, koronki itd. Wszystko z Niemiec pochodzić musiało ${ }^{28}$.

Relacja generałowej nie kończy się jednak na samym tylko Paryżu. Wiosną i latem 1834 roku księżna Giedroyciowa i jej córki bawiły w Wersalu, który pełen był Polaków. Niedaleko nich, na pagórku Bellevue w osobnym mieszkaniu zatrzymał się Mickiewicz, spędzając czas nad korektą Pana Tadeusza i odwiedzając przebywających w Sevrés rodaków ${ }^{29}$. Wizyty składała również Rautenstrauchowa, jednej z nich poświęciła nawet fragment swojej książki. Została mianowicie zaproszona

\footnotetext{
27 Łucja z książąt Giedroyciów Rautenstrauchowa, dz. cyt., s. 4042.

28 Tamże, s. 171-174.

29 Maria Dernałowicz, dz. cyt., s. 310.
} 
na obiad do Laury Junot, księżnej d'Abrantés ${ }^{30}$. Jak wspomina: „Było to dnia 29 lipca 1834 r. Znalazłam ją poufale i wesoło z młodym człowiekiem rozmawiającą. Przystojny ten mężczyzna, ładnej twarzy, łagodnego spojrzenia, miał lewą rękę zawieszoną na chustce"31. Jak się okazało tego samego dnia wizytę hrabinie składał Victor Hugo a

mowa jego równie przyjemna jak cała powierzchowność, w tej przynajmniej poufałej gawędce zupełnie $\mathrm{z}$ nią harmonizowała, a $\mathrm{z}$ pismami jego w największej była sprzeczności [...] pełna wrażenia dzieł jego, tak byłam pewną, iż on musi mieć oczy zapadłe i jaskrawe, cerę żółtą, lica wychudłe, włosy długie i rozczochrane, słowem coś, co Mickiewicza przypominać miało, że ujrzawszy twarz wyrazu miłego, bez wąsów, bez faworytów, włosy starannie uczesane, równą staranność w całej osobie, nie przypuszczałam wcale, aby to mógł być [...] Hugo ${ }^{32}$.

Młody pisarz zabawiał obie damy rozmową, opowiadając, jak wraz z przyjaciółmi w Lasku Bulońskim dla rozrywki i umilenia sobie czasu jeździli na osłach, gdy zdarzył się nieprzyjemny wypadek, jak wspominał Hugo: ,[...] całe towarzystwo poklaskiwało memu zwycięstwu, lecz niebawnie nieczuły na mą sławę osioł, pogardzając swym w niej udziałem, umyślił wyłamać się z pod niemiłego jarzma. Zaczął co raz częściej tylnimi nogami brykać, nareszcie tak zuchwały bryk zrobił, żem się w sromotnej postaci w głębokim rowie ujrzał. Przenosiny moje były tak gwałtowne, iż je zwichnięciem ręki opłaciłem [...]"33. Księżna d'Abrantes, z największym zrozumieniem słuchająca historii pisarza, sama również opowiedziała o podobnym wypadku, który był jej udziałem. Na szczęście poza drobnym stłuczeniem nie doznała poważniejszych obrażeń. Sama generałowa słuchała tego z jak największym zdziwieniem: ,,pomyślałam sobie, że [...] nie jeden zdziwiłby się bardzo, a może i zgorszył gdyby słyszał Victora Hugo z księżną d'Abrantes

30 Laura z domu Permon, księżna d'Abrantés (1784-1838), żona Andoche Junota, przyjaciela i adiutanta Napoleona.

31 Łucja z książąt Giedroyciów Rautenstrauchowa, dz. cyt., s. 348.

32 Tamże, s. 350.

33 Tamże. 
długo rozmawiającego... o osłach!...” ${ }^{\text {34 }}$. Co więcej znany pisarz, „obojętny dla obecnych, zimny dla nieznajomych, ani się zapytał kto jestem i nie żądał być mnie przedstawionym [... $]^{\prime 35}$. Dopiero po chwili hrabina zreflektowała się, tłumacząc, że Hugo, powszechnie znany we Francji, nie przywykł do przedstawiania się innym. Jednak nie zmyliło to bynajmniej Rautenstrauchowej, gdyż ta od dawna wiedziała, z kim przestaje. Jak wspomina:

wtenczas powtórny przegląd uczyniwszy głowy, w której koniecznie coś jenialnego wypatrzyć pragnęłam, postrzegłam, iż twarz miłą i ujmującą zakończa niepospolicie wzniosłe czoło, a szczególniej szerokie. Prócz czoła nic pana Hugo od reszty śmiertelnych nie różni i można by tysiąc razy go minąć nie zapytawszy, kto jest. Mickiewicz daleko bardziej romantyczną ma powierzchowność, wyraz oczu jego nie do określenia, pod jego wzrokiem nieraz obojętnie przejść nie można, gdy to spojrzenie z całą bystrością spuści się na ciebie, bądź pewnym, iż się wskroś przeszytym uczujesz. Niekiedy przymdlone się błąka... natenczas widzisz w nim całą głębokość nie objętych Beethovena kompozycji... melodią fantastycznych improwizacji Chopina... czasem znów zdają się nim sklepienia niebios przedzierać, wieki odgadywać, przyszłość zgłębiać, pojmować. Wtenczas widać w tych oczach, że ziemia z przed nich znikła... w ten czas i tylko wtenczas Mickiewicza malować by trzeba ${ }^{36}$.

Mając tak wielkiego pisarza za porównanie naturalnym jest, że Hugo nie mógł dorównać Polakowi.

Rautenstrauchowa spędziła we Francji sześć lat. Był to, zdaje się, najciekawszy i obfitujący w wiele wrażeń oraz nowych znajomości okres w jej życiu. Poczynione tu kontakty owocowały w jej późniejszym życiu. Kilkukrotnie także wracała jeszcze do Paryża: w 1840 (z tego pobytu wydała w 1842 książkę Ostatnia podróż do Francyi, która stanowi uzupełnienie Wspomnień moich o Francyi), 1850, 1859 oraz 1868 roku.

\footnotetext{
34 Tamże, s. 354

35 Tamże.

36 Tamże, s. 356
} 
Życie tej pisarki jest doskonałym potwierdzeniem słów zawartych w tytule mojego opracowania: „Aby pojąć Paryż, trzeba długo żyć z Paryżem". Miasto to było bez przerwy obecne w życiu Rautenstrauchowej (mieszkały w nim jej matka i siostra) i mimo że nie przebywała w nim na stałe, to jednak dostatecznie długo, by mogła je poznać, nabrać dystansu do tej światowej stolicy mody i opisać ją taką, jak ją postrzegała: „nie przewodniczy mi bynajmniej myśl dumna wykształcenia doskonałego Francji obrazu"37. Pisarka dotrzymała słowa, z jej dzieła wyłania się miasto pełne sprzeczności, z jednej strony piękne i dumne, z drugiej biedne i zaniedbane. Dbające o pozory, udające grzeczność i dobre maniery, by za chwilę pokazać swą drugą, zachłanną twarz. Motyw „Cicerone” - tajemniczego przewodnika pokazującego nowoprzybyłej do miasta uroki stolicy niezmiennie nasuwa wymowne skojarzenie z Dantem i Boską komedią, co pośrednio również tłumaczy stosunek pisarki do Paryża.

Wspomnienia moje o Francyi ukazały się w 1839 roku. Wydarzenie to przeszło jednak bez większego echa - prawdopodobnie ze względu na zbyt krytyczne uwagi dotyczące Paryża. To, co ponad sto siedemdziesiąt lat temu poczytywano za słabość autorki, dziś stanowi o jej ogromnej sile. W ciągu ostatnich kilkudziesięciu lat XIX wiek był przedmiotem wielu badań, nieco uwagi poświęcono również Rautenstrauchowej w kontekście jej podróży do Włoch i książki $W$ Alpach i za Alpami, która - jak dotąd - jest jej najbardziej znanym dziełem. Wspomnienia moje o Francyi nadal traktowane są z rezerwą i uznawane za niezbyt udane literacko. Niesłusznie. Chłodny dystans obserwacji czynionych przez Rautenstrauchową stawia Wspomnienia... na równi z jej innymi literackimi dokonaniami.

37 Tamże, s. 6. 


\section{Summary}

'To grasp Paris, one has to live with Paris for a long time'. French impressions from journeys of Lucja Rautenstrauch from the ducal family of Giedroyć

The article is a short attempt to present the reader with a profile of the now-forgotten Łucja Rautenstrauch from the ducal family of Giedroyć, a nineteenth century writer and traveller, who gained her fame and appreciation in the epoch thanks to her travel writings. Two of Łucja Rautenstrauch's works deserve special attention: My memories of France [Wspomnienia moje o Francyi] and The last journey to France [Ostatnia podróż do Francyi], where she gave an impartial description of Paris. The author depicts the city pointing both to its good and bad sides. Her memories distinguish themselves from among other travel writings because of the author's unusual sense of perception and the accuracy of her remarks. One will not find any instances of artificial admiration nor unnecessary humility in front of the people who meant more than her. On the contrary, an image of an educated aristocrat who does not feel the obligation to uphold the rules of the world she did not appreciate emerges for My memories of France. In the same work Łucja Rautenstrauch focuses on the description of the visible and external world: the customs, fashion, the French street, the salon and the history of the visited places. 